\title{
БІОТЕХНОЛОГІЧНІ КУЛЬТУРИ В СУЧАСНОМУ АГРАРНОМУ СЕКТОРІ
}

\section{Рецензент - доктор сільськогосподарських наук В. М. Тищенко}

\begin{abstract}
Представлено широкий огляд генетично модифікованих культур за новими ознаками. На основі зібраних даних наведено характеристику основних ознак, притаманних сучасним біотехнологічним культурам: толерантність до гербіцидів, стійкість до пошкодження комахами, стійкість до вірусних хвороб та інші. Аналіз даних показав, щзо всі чужорідні гени, вбудовані в рослини, мають бактеріальне, рослинне або вірусне походження. Найбільшого розповсюдження в світі набули генетично модифіковані лінії кукурудзи та сої.
\end{abstract}

Ключові слова: біотехнологічні культури (генетично модифіковані рослини), ознаки, чужорідні гени, розповсюдження, законодавство.

Постановка проблеми. Біотехнологія, в тому числі й створення генетично модифікованих (ГМ) - так званих біотехнологічних культур, $\epsilon$ одним із перспективних напрямів сучасної науки, який стрімко розвивається. Подібна хвиля нових сортів і ліній ГМ-рослин, звичайно, викликає певні занепокоєння у суспільства, деяких аграріїв, політиків і представників науки. Тому лише раціональний і всебічний аналіз протягом тривалого часу зможе заспокоїти споживачів й виробити чіткі норми для впровадження продуктів генетичної інженерії в світі. Як і в усіх країнах світу, в України існує потреба у визначенні засад державної політики в питанні біобезпеки вирощування ГМ-культур і дозволу продуктів, що містять генетично модифіковані компоненти.

Аналіз основних досліджень i публікацій, у яких започатковано розв'язання проблеми. За словами прибічників генно-інженерних технологій, необхідність вирощування ГМ-культур продиктована збільшенням виробництва продовольства у зв язку з поширенням на планеті голоду, а також підвищенням попиту на продовольчі культури для виробництва біопалива [14]. До 2050 року кількість людей, які потерпають від голоду, подвоїться й становитиме 1,8 мільярда [11].

Тим паче, нові ГМ-рослини будуть більш стійкі до посухи та шкідників, що може забезпечити стабільний рівень врожайності цих культур навіть за умов глобальних кліматичних змін.
Генетично модифікований організм (ГМО) це організм, генотип якого було змінено за допомогою методів генетичної інженерії. Генетичний матеріал переносять 3 одного організму в інший, використовуючи так звану технологію рекомбінантних ДНК. Якщо при цьому ДНК, яку переносять, походить 3 іншого виду, отримані організми називають трансгенними [3]. Першою ГМ-рослиною був тютюн, стійкий до вірусної інфекції, отриманий в США у 1983 році, а в 1994, після проходження всіх тестів на токсичність, алергенність і мутагенність, у США 3'явилися перші трансгенні продукти. Це були томати сорту Flavr Savr, які характеризувалися затримкою дозрівання плодів, створені фірмою Calgen, а також стійка до обробки гербіцидом соя фірми Monsanto [8].

У цілому, створюючи ГМ-рослини, сучасна наука може вирішувати такі завдання: а) покращання якості продукції (метаболізм вуглеводів і жирних кислот, затримка дозрівання, зменшення вартості переробки); б) стійкість до шкідників (бактерій, грибів, вірусів, комах, нематод); в) агрономічні показники (стійкість до посухи, толерантність до гербіцидів, зменшення потреби в азотному живленні, стійкість до засолення, стійкість до температурних факторів); г) екологічні біотехнології (зв'язування органічних полютантів і важких металів); д) синтез фармацевтичних препаратів та інших сполук: синтез вакцин, гормонів, фармацевтичних білків та моноклональних антитіл, синтез мономерів біодеградуючого пластику $[3,8,14]$.

Масштабне промислове виробництво ГМкультур у світі розпочалося у 1996 році - на той час вони займали 1,7 млн гектарів [1]. За період із 1996 по 2013 рік площі під цими культурами зросли до 170 млн гектарів. У 2013 році в світі було висіяно 175,2 млн гектара біотехнологічних рослин, що на $3 \%$ більше, ніж у 2012 році. Таким чином, можна констатувати постійне нарощування об'ємів виробництва ГМ-культур за 18 років із початку їх масштабного вирощування в 1996 році, яке збільшилося в 100 разів. ГМкультури вирощували в 2013 році 27 країн, 8 із них - це розвинені країни, 19 - ті, що розвива- 


\section{СІЛЬСЬКЕ ГОСПОДАРСТВО. РОСЛИННИЦТВО}

ються. 310 країн, найбільших за площами вирощування, 8 - це ті, що розвиваються. Латинська Америка, Африка й Азія сукупно вирощують 94 млн гектарів, або 54 \% від світового об'єму вирощування ГМ-культур [12, 13]. США, безсумнівно, продовжує залишатися світовим лідером у вирощуванні ГМ-культур. Це 70,1 млн гектарів, або 40 \% від світового об'єму; тут дозволені до вирощування близько $90 \%$ від усіх зареєстрованих у світі ГМ-культур. На другому місці Бразилія, де на площі 40,3 млн гектара вирощують, в основному, три ГМ-культури - сою, кукурудзу та бавовник. Аргентина має 24,4 млн гектари під соєю, кукурудзою та бавовником; Індія вирощує ГМ-бавовник на 11 млн гектарів. Завершує п’ятірку лідерів Канада, яка на площі 10,8 млн га вирощує сою, кукурудзу, ріпак, цукровий буряк та інші культури. Інші країни, такі як Китай (4,2 млн га), Парагвай (3,6 млн га), Південна Африка (2,9 млн га), Пакистан (2,8 млн га) активно збільшують площі під ГМ-культури. В 2013 році 5 європейських країн, передусім Іспанія $(136,962$ га), вирощували Вt-кукурудзу на 148,013 гектар. Зауважимо, що країни СС стриманіше відносяться до швидкого впровадження біотехнологічних культур у своє виробництво. Так, Німеччина в 2013 році практично відмовилася від вирощування ГМ-картоплі, Португалія, Чехія та Словакія зменшили посівні площі під Вt-кукурудзою [13].

Мета і завдання досліджень. Метою нашої роботи $\epsilon$ вивчення стану поширення генетично модифікованих (ГМ) культур у світі, аналіз нових ознак і генів, що їх обумовлюють, та надання достовірної інформації про весь спектр
ГМ-культур, які сьогодні дозволені до вирощування.

Головним завданням даного дослідження було проаналізувати дозволені до вирощування сільськогосподарські ГМ-культури за новими ознаками, а також показати й описати генетичну природу цих ознак.

Матеріали і методи досліджень. У процесі роботи були використані офіційні джерела інформації, які представляють достовірні дані про стан поширення та реєстрації нових ГМ-культур. Такими джерелами $є$ електронні ресурси Міжнародної служби з впровадження агробіотехнологічних здобутків (ISAAA), Продовольча та сільськогосподарська організація ООН (FAO), інші зарубіжні й вітчизняні наукові праці, а також Закони України, що стосуються біобезпеки використання досягнень генетичної інженерії.

Результати досліджень. На сьогодні в світі зареєстровано й дозволено до вирощування понад 340 генетично модифікованих ліній, які представляють 27 культур (табл. 1). Найбільше зареєстровано ГМ-ліній кукурудзи (132 ліній, 38 \% від загальної кількості), бавовнику (49 ліній, $15 \%)$, ріпаку (30 ліній, 9\%), картоплі (31 лінія, 9 \%) та сої (29 лінї, 8 \%) [12]. Ці ГМлінії та сорти несуть у своїх геномах чужорідні гени бактеріального, рослинного або вірусного походження. Ці гени контролюють різноманітні ознаки, які неможливо або досить складно надати рослинам традиційними методами селекції. Відомо 36 нових ознак, якими характеризуються різні ГМ-культури. До того ж можливі як поодинокі, так i комплексні включення цих нових ознак у сільськогосподарські культури.

\section{1. Культури, ГМ-лінії яких дозволені до вирощування}

\begin{tabular}{|c|c|}
\hline $\begin{array}{c}\text { Люцерна посівна (Medicago sativa) } \\
\text { Ріпак (Brassica napus) } \\
\text { Квасоля (Phaseolus vulgaris) } \\
\text { Гвоздика (Dianthus caryophyllus) } \\
\text { Цикорій (Cichorium intybus) } \\
\text { Бавовник (Gossypium hirsutum L.) } \\
\text { Польовиця (Agrostissto lonifera) } \\
\text { Льон (Linum usitatissumum L.) } \\
\text { Кукурудза (Zea mays L.) } \\
\text { Диня (Cucumis melo) } \\
\text { Папайа (Carica papaya) } \\
\text { Петунія (Petunia hybrida) } \\
\text { Слива (Prunus domestica) } \\
\text { Баклажан (Solanum melongena) }\end{array}$ & $\begin{array}{c}\text { Ріпа (Brassica rapa) } \\
\text { Тополя (Populus sp.) } \\
\text { Картопля (Solanum tuberosum L.) } \\
\text { Рис (Oryza sativa L.) } \\
\text { Троянда (Rosa hybrida) } \\
\text { Соя (Glycine max L.) } \\
\text { Гарбуз звичайний (Cucurbita pepo) } \\
\text { Цукровий буряк (Beta vulgaris) } \\
\text { Цукрова пальма (Saccharum sp.) } \\
\text { Перець овочевий (Capsicum annuum) } \\
\text { Тютюн (Nicotiana tabacum L.) } \\
\text { Томат (Lycopersicon esculentum) } \\
\text { Пшениця (Triticum aestivum) }\end{array}$ \\
\hline
\end{tabular}




\section{СІЛЬСЬКЕ ГОСПОДАРСТВО. РОСЛИННИЦТВО}

Аналіз та характеристика найбільи розповсюджених ГМ-культур. Соя. Однією $з$ перших культур у світі, до якої вдалося перенести чужорідний ген, була соя (Glycine max L.) [1, 3]. На сьогодні $93 \%$ посівів сої в світі займають ГМ-сорти сої [13]. Першою ознакою, що передана сої, була толерантність до гербіциду гліфосат, що контролюється геном cp4 epsps, донором якого є бактерія Agrobacterium tumifaciens strain CP4. Токсична дія гліфосату обумовлена тим, що він інгібує фермент рослин 5-енол-пирувілшикимат-3-фосфат синтетазу, яка відіграє важливу роль у синтезі трьох ароматичних амінокислот (фенілаланіну, тирозину та триптофану) і деяких інших важливих компонентів рослини. Тому в разі потрапляння гліфосату на рослини вони гинуть. У трансгенну, толерантну до гербіцидів сою внесений бактеріальний ген cp4 epsps ферменту, який не чутливий до гліфосату й який здійснює необхідну функцію в синтезі ароматичних амінокислот $[2,7]$. ГМ-соя дозволена до імпорту та вживання в їжу в більшості країн світу; водночас сівба і вирощування ï дозволені не в усіх країнах. Найбільше ГМ-сортів сої зареєстровано в США (19), Мексиці (15) та Новій Зеландії (12). Інші країни хоча й вирощують ГМ-сою, проте чітко обмежили асортимент дозволених сортів. Так, у Росії зареєстровано лише 5 сортів ГМ-сої, в СС - 7 сортів, Уругваї - 4 сорти, в Колумбії лише 1 лінію ГМ-сої [12]. Нами були проаналізовані всі дозволені до вирощування в різних країнах лінії сої за новими ГМ-ознаками. Показано, що серед 29 зареєстрованих ліній сої 25 мають ознаку толерантності до різних гербіцидів (гліфосат, глюфосинат та інші); 3 мають ознаку стійкості до пошкодження лускокрилими комахами-шкідниками; 7 - ознаку модифікованих жирних кислот. Також деякі лінії можуть нести у своєму геномі кілька чужорідних генів, відповідно, поєднувати кілька нових ознак. Наприклад, лінія DP305423 х GTS40-3-2 має у своєму генотипі 3 чужорідних гени, які забезпечують формування ознак стійкості до двох видів гербіцидів та змінений якісний склад насіння. Для створення 7-ми ГМ-ліній сої був використаний метод трансформації рослин за допомогою Тіплазміди, для 17 ліній - метод бомбардування мікрочастинками з використанням генної гармати [12].

Кукурудза (Zea mais L.) є однією з головних - поряд із пшеницею та рисом - зернових культур у світі, тому стабільний і високий рівень урожаю цієї культури актуальний для багатьох країн [11]. Одним із новітніх напрямів у селекції кукурудзи є використання методів генної інженерії. На сьогодні вже 86 \% посівів кукурудзи в світі займає генетично модифікована кукурудза, що характеризується найбільшою кількістю зареєстрованих ліній (132) 3-поміж інших ГМ-культур [10]. Крім того, кількість ГМ-ліній кукурудзи, дозволених до вирощування в різних країнах, досить сильно коливається: США - 38, Канада - 58, ЄC-39, Австралія - 21, Китай - 16, Росія - 11 [12].

Більшість ГМ-ліній кукурудзи характеризується толерантністю до обробки гербіцидами, а також стійкістю до пошкодження комахами-шкідниками. Ознака стійкості до комах забезпечується вбудуванням у геном рослини гену синтеза дельтаендотоксину (CRY-білок). Природнім шляхом цей білок синтезується бактерією Bacillus thuringiensis, яка вже впродовж багатьох років використовувалася в препаратах захисту рослин від комахшкідників, чим довела безпечність свого застосування. Її білок CRY є токсичним для комах, при цьому різні штами бактерії продукують специфічні токсини до певних видів комах $[2,9]$. Використовуючи методи генної інженерії, вченим вдається вбудовувати ген цього білку в геном рослини, в результаті чого рослина набуває стійкості до пошкодження певним видом комах. У такий спосіб створені ГМ-рослини картоплі, кукурудзи, бавовнику, тютюну [8, 12]. У ГМ-кукурудзи ген cryla контролює синтез білків класу CRYI, які є токсичними для лускокрилих комах та їх личинок; ген cry3 контролює синтез білків класу CRYIII, токсичних для твердокрилих комах та їх личинок $[2,7]$. Bt-рослини є більш екологічними, в порівнянні 3 гербіцидстійкими, оскільки не потребують застосування на ïх посівах інсектицидів. Зазвичай, тільки 5 \% внесених інсектицидів спрацьовує за призначенням, а $95 \%$ потрапляє в оточуюче середовище, забруднюючи водні джерела та знищуючи корисних комах [11]. Сучасними напрямами генетичного покращання кукурудзи $є$ надання рослинам ознаки стійкості до посухи, що в майбутньому може забезпечити стабільний врожай кукурудзи в умовах глобальної зміни клімату, а також надання ознак змінених якісних показників рослинної продукції (змінений склад жирних кислот, амінокислотний склад), чоловіча стерильність [14]. Нами були проаналізовані всі дозволені до вирощування та використання в селекційному процесі лінії кукурудзи за новими ГМ-ознаками. Серед 132 зареєстрованих ліній кукурудзи понад 100 ліній мають ознаку толерантності до різних гербіцидів (гліфосат, глюфосинат та інші); 90 - ознаку стійкості до пошкодження лускокрилими комахами-шкідниками; 65 - до твердокрилих; 25 несуть гени стійкості до антибіотиків; 6 мають чужорідний ген чоловічої стерильності; 4 лінії - гени стійкості до посухи; 8 ліній - гени модифікованої альфа амілази та 2 лінії мають модифікований амінокислотний склад (рис. 1) [12]. 


\section{СІЛЬСЬКЕ ГОСПОДАРСТВО. РОСЛИННИЦТВО}

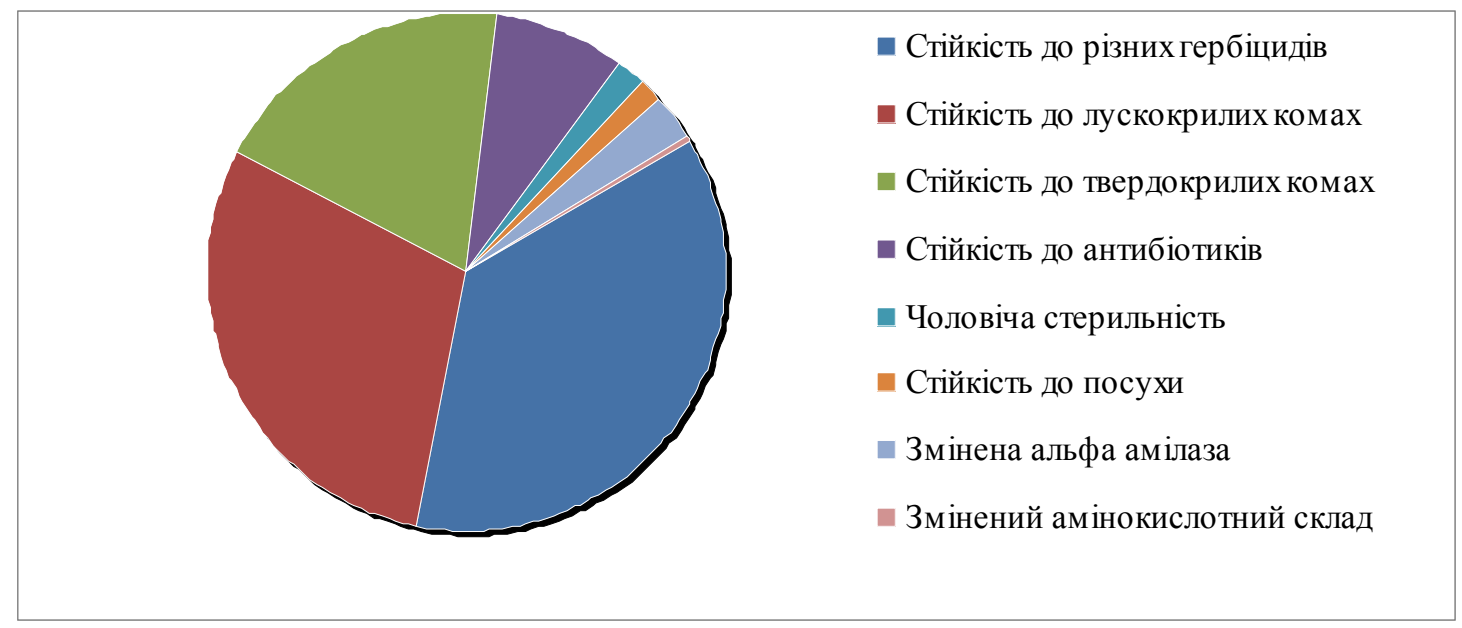

Рис. 1. Ознаки, якими характеризуються ГМ-лінії кукурудзи (за даними ISAAA, 2014)

Для створення ГМ-ліній кукурудзи найчастіше використовують такі методи переносу генів, як метод трансформації рослин за допомогою Ті-плазміди (15 ГМ-ліній) та метод бомбардування мікрочастинками (20 ліній), а також схрещування ГМ-ліній між собою традиційними методами селекції (86 зареєстрованих ліній). Найчастіше новим ГМ-лініям кукурудзи надають кілька ГМ-ознак. Так, ліній, які несуть у собі лише один чужорідний ген, лише 7; 2 чужорідні гени мають 27 ліній; 3 нових гени - 47 ліній; 4, 5 і 6 нових генів, відповідно, 26, 12 та 4 лінії [12]. Нові ознаки ГМ-сої та кукурудзи дають змогу полегшити технологію вирощування цих культур, а також підвищити стійкість рослин до обробки гербіцидами, до пошкодження комахами, змінити якісний склад насіння сої й кукурудзи за допомогою методів генетичної інженерії. Тим не менше, для гарантування продовольчої безпеки населення нові ГМ-лінії сої та кукурудзи потребують ретельного аналізу впродовж тривалого періоду. У даній роботі проаналізовані основні ознаки, притаманні біотехнологічним культурам. $\mathrm{У}$ розширеній таблиці 2 подана характеристика цих ознак, описана їх генетична природа, продукт, який синтезується під контролем цих чужорідних генів, і функція, яку вони здійснюють у рослині.

Біобезпека. Масштаби досліджень та сфера застосування ГМО з року в рік зростають, що вимагає створення національних і міжнародних систем біобезпеки в роботі з генетично модифікованими організмами з метою запобігання їх неконтрольованого розповсюдження та використання. 3 цією метою в 1999 році був сформульований «Картахенський протокол із біобез- пеки». Це міжнародна угода про заходи та процедури, необхідні для безпечного переміщення через державні кордони, переробки й застосування продуктів сучасної біотехнології. Країни, що підписали iї, зобов'язані гарантувати, що в процесі обробки, пакування та транспортування ГМО дотримуються всіх заходів безпеки. Виконання положень Протоколу спрямоване на збереження біорізноманіття та біосфери. 3 наукової точки зору, ГМорганізми ще недостатньо вивченні в плані взаємодії з іншими природними екосистемами, тому потенційно можуть бути небезпечними для біосфери Землі й здоров'я людини. Можливе також витіснення ГМ-культурами звичайних та дикорослих рослин, перезапилення ГМ-пилком дикорослих співродичів культурних рослин, одночасно чужорідні гени можуть вийти в дику природу.

Стосовно побоювань споживачів щодо небезпеки вживання в їжу продуктів, що містять ГМкомпоненти, то необхідно зазначити, що, за даними ФАО, середньостатистична людина в день із продуктами з"їдає 0,1-1 г ДНК [11]. Продукти, що складаються 3 запасаючих органів рослин, таких, як картопля або пшениця, містять мало ДНК. Рафінований цукор взагалі не містить або містить слідові кількості ДНК. Чимало ДНК міститься у тканинах тварин, дріжджових грибах, бактеріях [2]. За звітами Європейської Комісії «Дослідження безпечності генетично модифікованих організмів за фінансового сприяння Свропейської комісії» (1985-2000) та «Десятиліття досліджень ГМО за фінансування Свропейського Союзу», не виявили наукових доказів, які б асоціювали ГМО з більш високими ризиками, ніж ризики від традиційних рослинних і живих організмів $[11,14]$. 


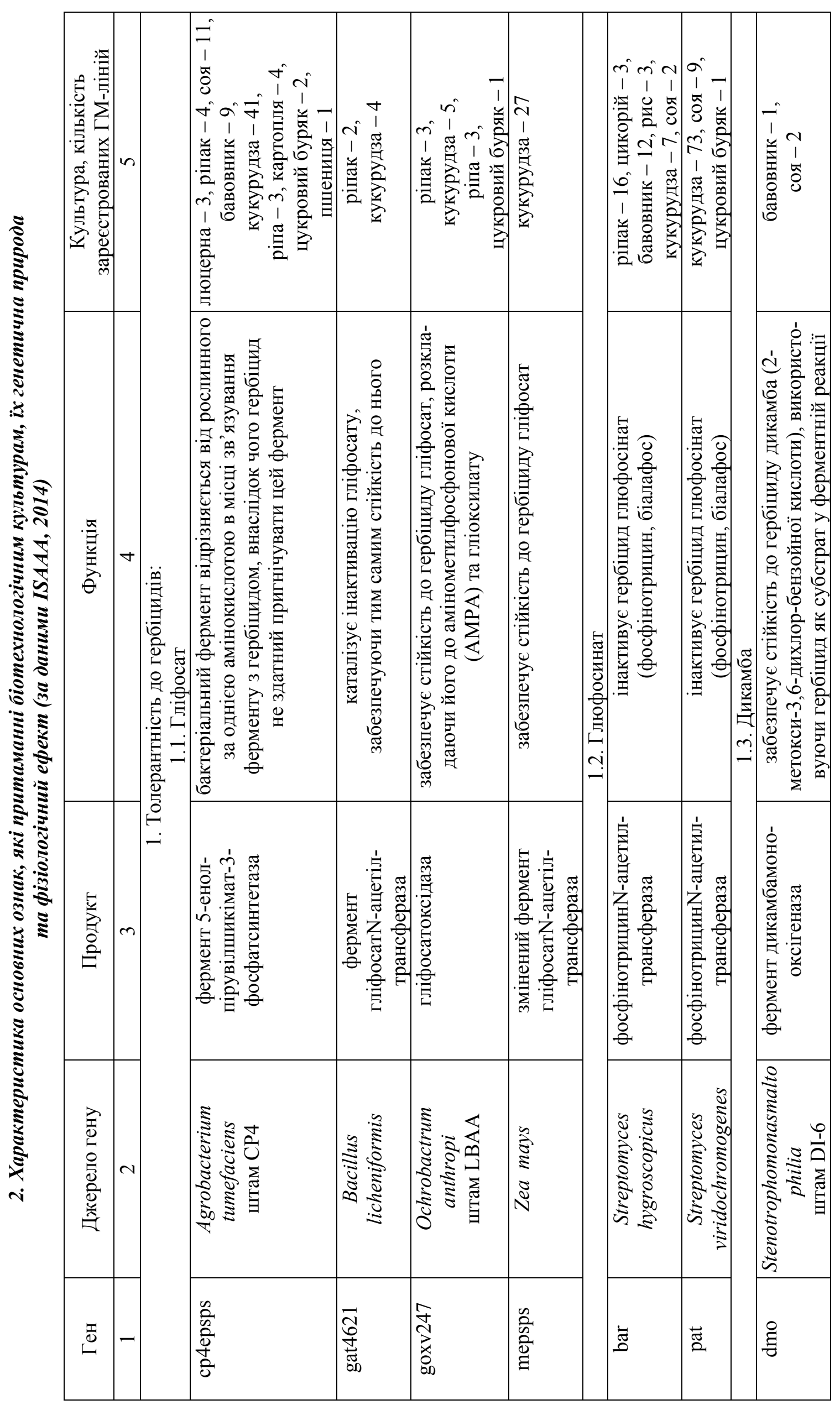




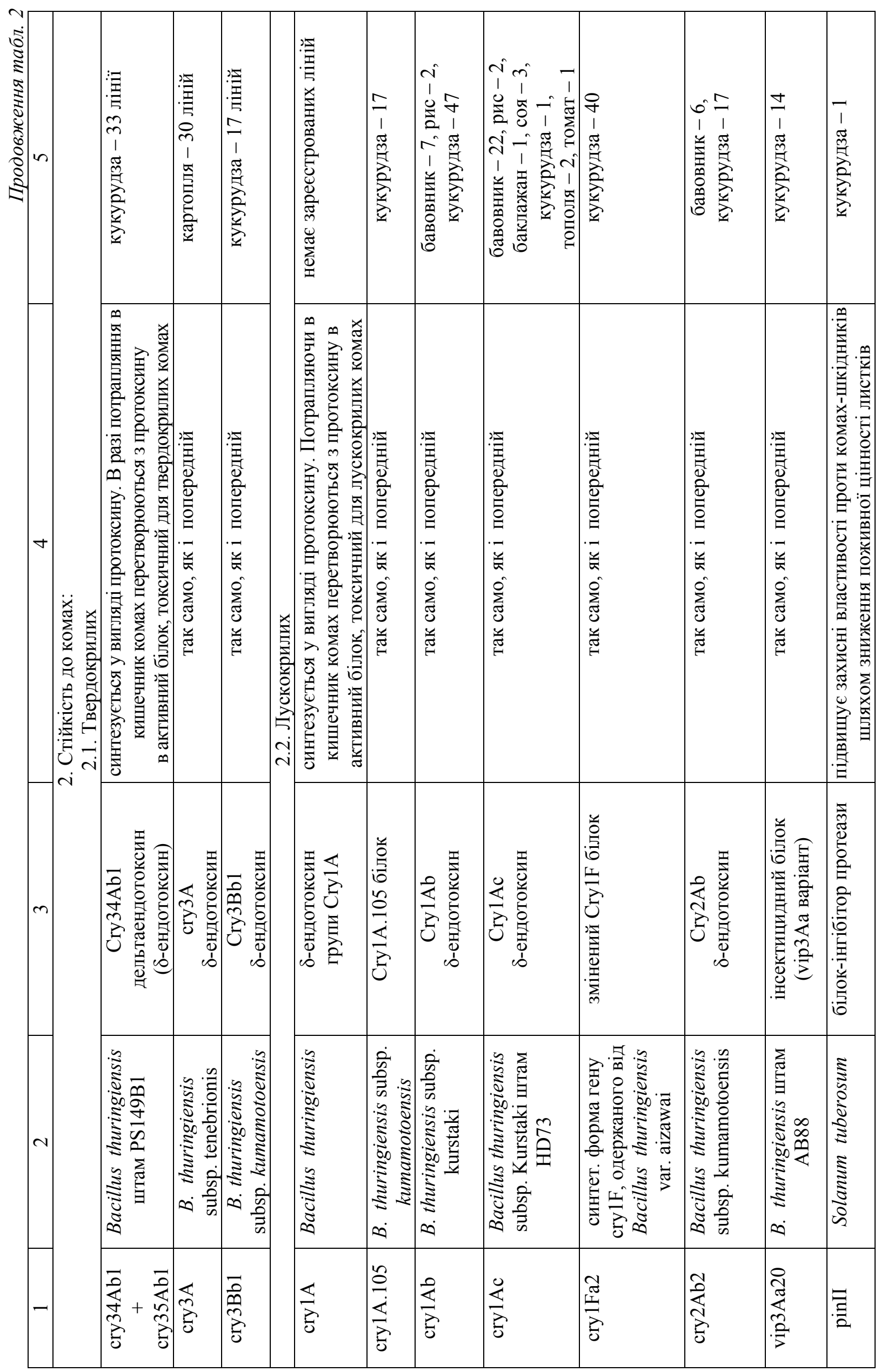




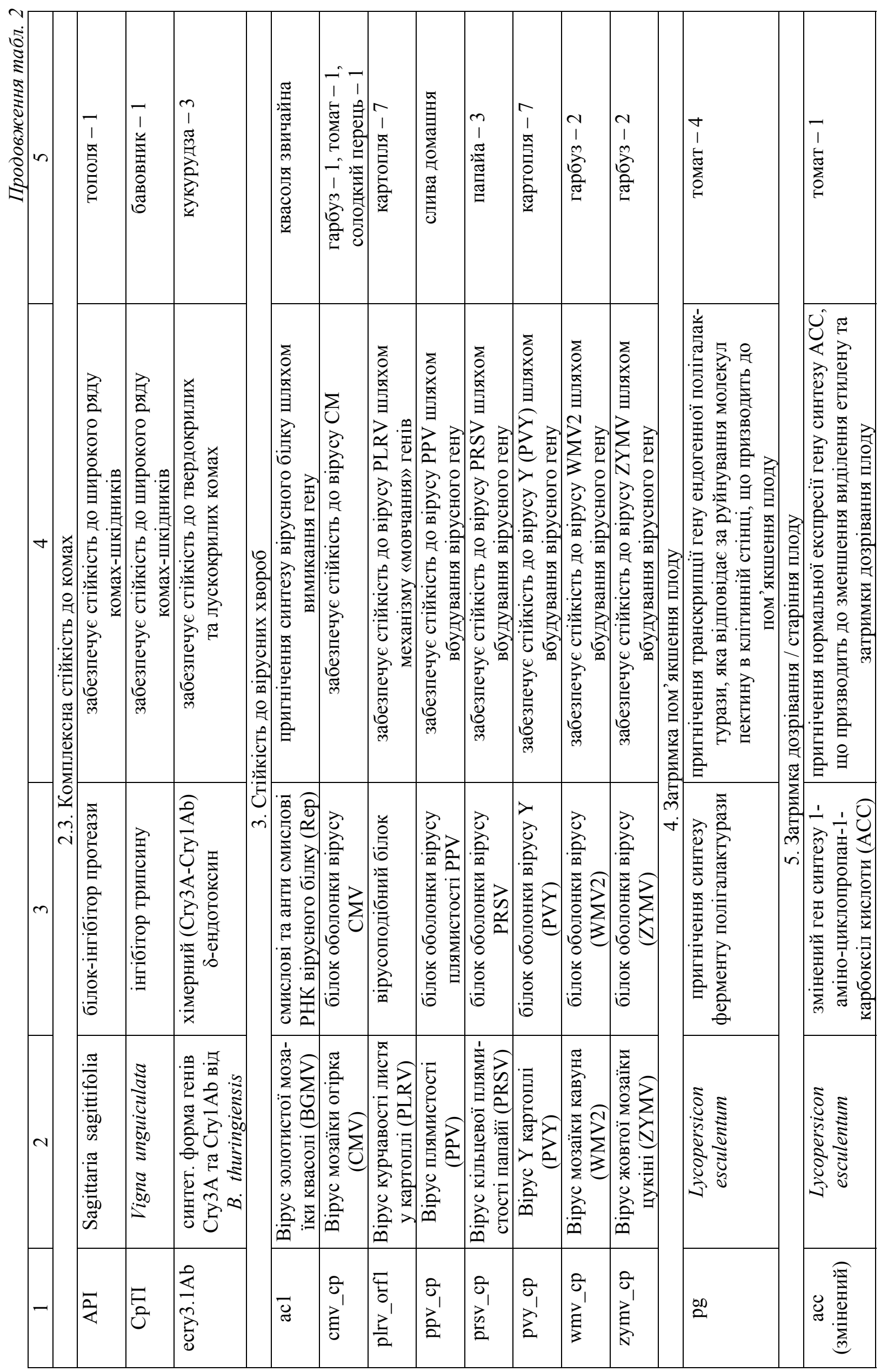




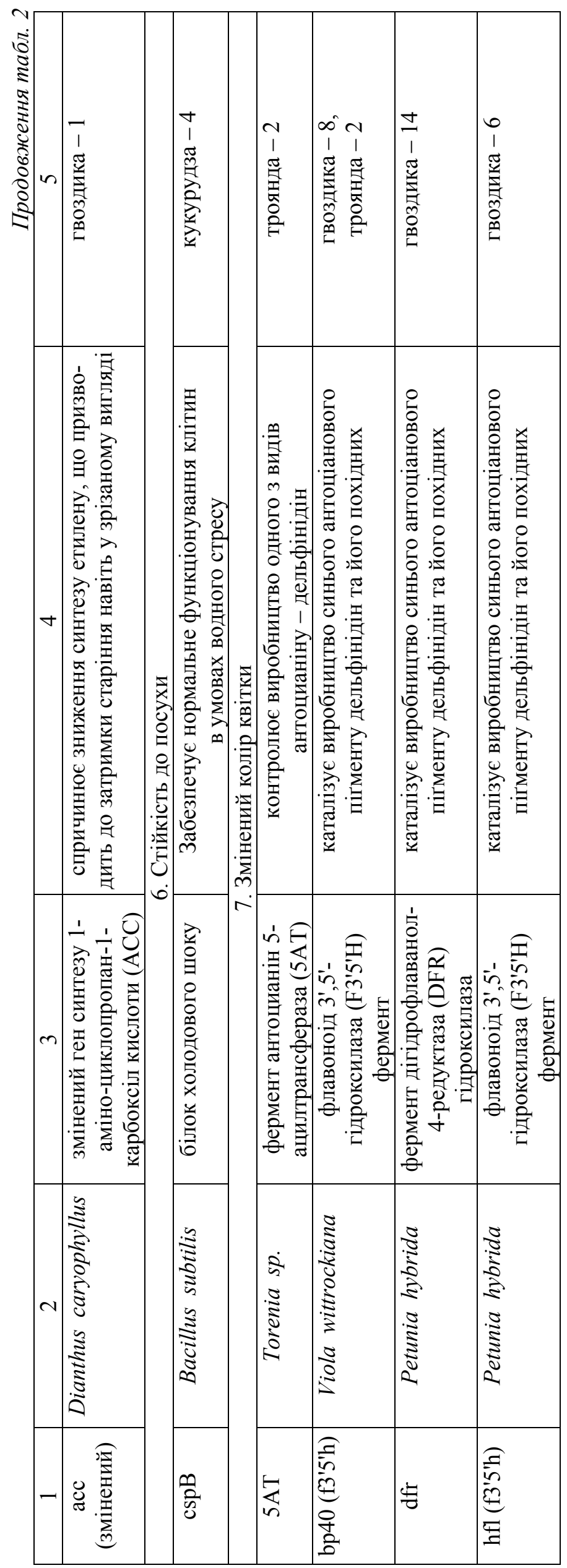




\section{СІЛЬСЬКЕ ГОСПОДАРСТВО. РОСЛИННИЦТВО}

Регулювання активності стосовно ГМО впроваджене в США та в країнах Західної Європи. У країнах так званого «третього світу», в Азії, Африці та Латинській Америці, впровадили національне законодавство стосовно регуляції, вивільнення та маркування генетично модифікованих рослин як для комерційної мети, так і для наукових цілей. Практично всі країни-сусіди України мають законодавчо-нормативну базу, що регулює генноінженерну активність і правила поводження з ГМорганізмами. України в цьому списку, на жаль, i досі немає. В Україні допуск ГМ-продуктів регулюють Закон «Про державну систему біобезпеки при створенні, випробуванні, транспортуванні та використанні генетично модифікованих організмів» [4] та Закон «Про захист прав споживачів», а саме Стаття 15. п. 5, де зазначається, що інформація про продукцію повинна містити позначку про наявність або відсутність у складі продуктів харчування генетично модифікованих компонентів [5]. Таким чином, маркуванню підлягають не тільки продукти, отримані з ГМО, а також харчові добавки, отримані за допомогою ГМО. Ні Європейське, ні законодавство Сполучених Штатів не передбачає маркування харчових добавок, отриманих за допомогою генетично модифікованих мікроорганізмів. Окрім того, Україна стала першою державою в світі, яка зобов'язала виробників та імпортерів харчових продуктів вказувати позначення «Без ГМО» в маркуванні всіх без винятку харчових продуктів, навіть тих, у

\section{БІБЛІОГРАФІЯ}

1. Брукс Г. ГМ-культуры: итоги первых десяти лет - глобальные социально-экономические и экологические последствия / Г. Брукс, П. Барфут. ISAA. - Выпуск №36. - Нью-Йорк, 2006. - 123 с.

2. Генетически модифицированные источники пищи: оценка безопасности и контроль : [под ред. В. А. Тутельяна]. - М. : Изд. РАМН, 2007. - 444 с.

3. Глазко В. И. Генетически модифицированные организмы: от бактерий до человека / В. И. Глазко. - К. : КВІЦ, 2002. - 209 с.

4. Закон України «Про державну систему біобезпеки при створенні, випробуванні, транспортуванні та використанні генетично модифікованих організмів» [Електронний ресурс]. - Режим доступу: http:/zakon1.rada.gov.ua/laws/show/1103-16.

5. Закон України «Про захист прав споживачів» [Електронний ресурс]. - Режим доступу: http:/zakon4.rada.gov.ua/laws/show/1023-12.

6. Кучук Н. В. Генетическая инженерия высших растений / Н. В. Кучук. - К. : Наук. думка, 1997. - $152 \mathrm{c}$.

7. Сиволап Ю. М. Вариабельность и специфичность геномов сельскохозяйственных растений / яких ГМО не може бути ні теоретично, ні практично. У результаті незаконного і неконтрольованого вирощування генетично модифіковані культури поширилися по всій території України. Окремі експерти вважають, що близько одного мільйона гектарів української землі зайнято ГМ-культурами, 3 яких понад 50 \% припадає на сою, $20 \%$ - на кукурудзу, решта - на картоплю та буряки. Маркування продуктів на наявність у них ГМО - це вимога в рамках закону. Проте такий крок виявився ненадійним і малодоцільним в Україні, де офіційно ГМкультури не вирощують.

Висновок. На підставі опрацьованої значної кількості літературних джерел можна стверджувати про незворотній процес залучення ГМ-рослин в аграрне виробництво в світі. Хоча в нашій країні й діє Закон про заборону вирощування й розповсюдження ГМ-культур і продуктів, що містять генетично модифіковані компоненти, однак у світовому аграрному виробництві спостерігається загальна тенденція до росту посівних площ під ГМ-культурами (170 млн га), розширення асортименту ГМ-ліній, пошук нових генів, нових ознак, зростають темпи впровадження генно-інженерних технологій у рослинництво. Відмічено, що існує суттєва різниця між різними країнами за асортиментом ГМ-культур, що дозволені до вирощування. Найбільш розповсюдженими ГМ-культурами у більшості країн світу $є$ кукурудза (понад 100 зареєстрованих ліній) та соя (понад 20 зареєстрованих ліній).

Ю. М. Сиволап, Н. Э. Кожухова, Р. Н. Календарь. - Одесса : Астропринт, 2011.-335 с.

8. Сорочинський Б. В. Генетично модифіковані рослини / Б. В. Сорочинський, О. О. Данильченко, Г. В. Кріпка. - К. : Фітосоціоцентр, 2005. - С. 203.

9. Чесноков Ю. В. Генно-инженерные манипуляции у растений и их естественная основа / Ю. В. Чесноков. - СПб. : ВИР, 2007. - 79 с.

10. Beyond promises: Top 10 Facts about Biotech / GM Crops in 2012 [Електронний ресурс]. - Peжим доступу: http: www.isaaa.org.

11. Food and Agriculture Organisation of the United Nations [Електронний ресурс]. - Режим доступу: http:www.fao.org.

12. GM Approval Database [Електронний peсурс]. - Режим доступу: http: www.isaaa.org.

13. James C. Global Status of Commercialized Biotech/GM Crops: 2013. / ISAAA Brief No. 46. [Електронний ресурс]. - Режим доступу: http://www.isaaa. org/resources/publications/briefs/46/default.asp

14. Plain Facts about GMOs. Hungarian white paper // Editors: E. Balazs, D. Dudits, L. Sagi. Szeged, 2011. $-136 \mathrm{p}$. 